\title{
HYPERCALCITONINEMIA IS NOT PATHOGNOMONIC OF MEDULLARY THYROID CARCINOMA
}

\author{
Sergio PA Toledo, ${ }^{\mathrm{I}}$ Delmar M Lourenço Jr, ${ }^{\mathrm{I}}$ Marcelo Augusto Santos, ${ }^{\mathrm{I}}$ Marcos R

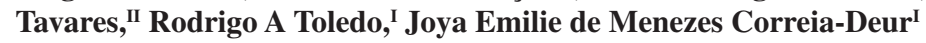

doi: 10.1590/S1807-59322009000700015

Toledo SPA, Lourenço Jr DM, Santos MA, Tavares MR, Toledo RA, Correia-Deur JEM. Hypercalcitoninemia is not pathognomonic of medullary thyroid carcinoma. Clinics. 2009;64(7):699-706.

Hypercalcitoninemia has frequently been reported as a marker for medullary thyroid carcinoma. Currently, calcitonin measurements are mostly useful in the evaluation of tumor size and progression, and as an index of biochemical improvement of medullary thyroid carcinomas. Although measurement of calcitonin is a highly sensitive method for the detection of medullary thyroid carcinoma, it presents a low specificity for this tumor. Several physiologic and pathologic conditions other than medullary thyroid carcinoma have been associated with increased levels of calcitonin. Several cases of thyroid nodules associated with increased values of calcitonin are not medullary thyroid carcinomas, but rather are related to other conditions, such as hypercalcemias, hypergastrinemias, neuroendocrine tumors, renal insufficiency, papillary and follicular thyroid carcinomas, and goiter. Furthermore, prolonged treatment with omeprazole ( $>2-4$ months), beta-blockers, glucocorticoids and potential secretagogues, have been associated with hypercalcitoninemia. An association between calcitonin levels and chronic auto-immune thyroiditis remains controversial. Patients with calcitonin levels $>100 \mathrm{pg} / \mathrm{mL}$ have a high risk for medullary thyroid carcinoma $(\sim 90 \%-100 \%)$, whereas patients with values from 10 to $100 \mathrm{pg} / \mathrm{mL}$ (normal values: $<8.5 \mathrm{pg} / \mathrm{mL}$ for men, $<5.0 \mathrm{pg} / \mathrm{mL}$ for women; immunochemiluminometric assay) have a $<25 \%$ risk for medullary thyroid carcinoma.

In multiple endocrine neoplasia type 2 (MEN2), RET mutation analysis is the gold-standard for the recommendation of total preventive thyroidectomy to relatives at risk of harboring a germline RET mutation (50\%). False-positive calcitonin results within MEN2 families have led to incorrect indications of preventive total thyroidectomy to RET mutation negative relatives.

In this review, we focus on the differential diagnosis of hypercalcitoninemia, underlining its importance for the avoidance of misdiagnosis of medullary thyroid carcinoma and consequent incorrect recommendation for thyroid surgery.

KEYWORDS: Calcitonin; False-positive test; RET mutation; Total thyroidectomy.

\section{INTRODUCTION}

Calcitonin is a polypeptide hormone composed of 32 amino acids that is secreted by thyroid C-cells. ${ }^{1}$ Serum calcitonin has been considered an excellent marker for medullary thyroid carcinoma (MTC). ${ }^{2}$ Until 1993, serum calcitonin measurement was the only reliable tool for the diagnosis of MTC..$^{2-6}$ However, further studies documented

${ }^{\text {I } U n i d a d e ~ d e ~ E n d o c r i n o l o g i a ~ G e n e ́ t i c a, ~ L a b o r a t o ́ r i o ~ d e ~ I n v e s t i g a c ̧ a ̃ o ~ M e ́ d i c a ~}$ (LIM-25), Hospital das Clínicas da Faculdade de Medicina da Universidade de São Paulo - São Paulo/SP, Brasil.

II Departamento de Cirurgia de Cabeça e Pescoço, Faculdade de Medicina da Universidade de São Paulo - São Paulo/SP, Brasil.

Email: toldo@usp.br

Tel: 55113061.7252

Received for publication on March 12, 2009

Accepted for publication on April 15, 2009 that calcitonin, as a tumor marker for MTC, presented falsepositive and false-negative results. ${ }^{4}$

There have also been reports of non-MTC patients who were erroneously submitted to total thyroidectomy due to recommendations based on elevated calcitonin values. ${ }^{7,8}$ It has been shown that only $10 \%$ to $40 \%$ of all patients with high levels of calcitonin associated with a thyroid nodule actually have MTC. ${ }^{9}$ Based on these observations, this review aims to emphasize physiologic and pathologic conditions other than MTC that may be associated with high serum levels of calcitonin.

\section{Calcitonin measurements}

Serum calcitonin values may be measured with several different assays. Radioimmunoassay (RIA) has been widely 
used, but this assay may measure calcitonin-like proteins, in addition to calcitonin. ${ }^{1,5,10}$ The first-generation method used in our hospital was an RIA (DPC, Los Angeles, CA) that used polyclonal antibodies to detect calcitonin; it had an upper normal value of $50 \mathrm{pg} / \mathrm{ml}$. The most common second-generation method is the immunoradiometry assay (IRMA), which uses two different antibodies to calcitonin (double-antibody method). It is more sensitive than the first-generation RIA and measures only the intact calcitonin molecule. ${ }^{1,11,12}$ The upper normal calcitonin value obtained by this method is $10 \mathrm{pg} / \mathrm{ml} .{ }^{11} \mathrm{~A}$ third-generation method for calcitonin detection, the immunochemiluminescent assay (ICMA), is now routinely used in our tertiary academic hospital. Normal basal calcitonin values detected by ICMA are lower than $5.0 \mathrm{pg} / \mathrm{ml}$ for women and lower than 8.5 $\mathrm{pg} / \mathrm{ml}$ for men (DPC, Los Angeles, CA). These two latter methods (IRMA and ICMA) are highly reliable and sensitive assays that use two antibodies to detect the monomeric form of the calcitonin molecule. Consequently, they are currently the two most commonly used methods.

\section{Sensitivity and specificity}

An elevated level of serum calcitonin is a highly sensitive marker for MTC, but it is not especially specific. ${ }^{9,13,14-20}$ Only $10 \%$ to $40 \%$ of all patients with thyroid nodules associated with high basal levels of calcitonin also had MTC. ${ }^{9}$ Therefore, in the remaining $60 \%$ to $90 \%$ of patients, elevated calcitonin values are secondary to other conditions (Table 1). Further, these results may also be due to problems in the methodology, the presence of endogenous anti-calcitonin antibodies, or even to chronic exposure to tobacco smoke. Also, serum calcitonin levels vary by sex, age, weight and physical activity. ${ }^{2,21-23}$

\section{Differential diagnosis of hypercalcitoninemia}

Before performing the diagnosis of MTC, the conditions shown in Table 1 and discussed below should be considered and discarded in cases with hypercalcitoninemia. As_seen in Table 2, the differential diagnosis of MTC should be the made in cases with basal calcitonin values between 10 and $100 \mathrm{pg} / \mathrm{mL}$ (determined by IRMA or ICMA).

Hypergastrinemia: High levels of gastrin stimulate the synthesis and secretion of calcitonin, therefore raising its serum levels. ${ }^{2-4}$ Gastrin, in the form of pentagastrin, is largely used in stimulatory tests that evaluate the capacity of C-cells ${ }^{5}$ to secrete calcitonin. Conditions associated with hypergastrinemia, such as atrophic gastritis and gastrinoma, may present increased levels of calcitonin. ${ }^{16}$

Omeprazole: The chronic use of omeprazole or
Table 1- Hypercalcitoninemia in non-medullary thyroid carcinoma conditions

\begin{tabular}{|c|c|}
\hline Physiologic conditions ${ }^{2,35,36}$ & $\begin{array}{l}\text { Sex } \\
\text { Age } \\
\text { Physical activity }\end{array}$ \\
\hline Drugs $^{2,29,32}$ & $\begin{array}{l}\text { Omeprazole and similar drugs (interfere } \\
\text { with the } \mathrm{H}^{+} \text {pump) } \\
\text { Glucocorticoids } \\
\text { Beta-blockers } \\
\text { Glucagon } \\
\text { CGRP } \\
\text { Enteroglucagon } \\
\text { Pancreozimine }\end{array}$ \\
\hline $\begin{array}{l}\text { Non-thyroid } \\
\text { pathologies } \\
\text { 2-4,5,28,29,34 }\end{array}$ & $\begin{array}{l}\text { Hypergastrinemias } \\
\text { Hypercalcemias (hyperparathyroidism) } \\
\text { Renal insufficiency } \\
\text { Neuroendocrine tumors: } \\
\text { pheochromocytoma } \\
\text { paraganglioma } \\
\text { enteropancreatic endocrine tumors } \\
\text { VIPoma } \\
\text { insulinomacarcinoids } \\
\text { small cell pulmonary tumor } \\
\end{array}$ \\
\hline $\begin{array}{l}\text { Thyroid } \\
\text { pathologies } 2,9,20,36,38,39,40\end{array}$ & $\begin{array}{l}\text { Thyroid carcinomas: } \\
\text { follicular carcinoma } \\
\text { papillary carcinoma } \\
\text { Chronic autoimmune thyroiditis* }\end{array}$ \\
\hline
\end{tabular}

Table 2 - Calcitonin values and risk for medullary thyroid carcinoma*

\begin{tabular}{ll}
\hline Value $(\mathrm{pg} / \mathrm{ml})$ & Risk for MTC \\
\hline$>100$ & Extremely high $(100 \%)$ \\
$\geq 50$ and $<100^{* *}$ & Moderate $(25 \%)$ \\
$\geq 20$ and $<50^{* *}$ & Low $(8.3 \%)$ \\
$<8.5$ for $\mathrm{men} /<5.0$ for women & Normal
\end{tabular}

* Based on Constante et al., 2007. ** It is recommended to systematically investigate non-MTC conditions in patients with calcitonin levels in these ranges.

omeprazole-like drugs raises calcitonin serum levels after 2 to 4 months of treatment. ${ }^{16,19}$ These drugs may lead to constant stimulation of gastric G-cells and induce gastrin hypersecretion, ultimately leading to high serum levels of calcitonin. Omeprazole's action on calcitonin levels is well recognized. It has been proposed as a potential stimulatory test for calcitonin secretion. ${ }^{24}$

Hypercalcemia: Calcium is a strong calcitonin secretagogue that is currently used to evaluate calcitonin secretion. In this test, calcium is acutely injected $(2 \mathrm{mg} /$ $\mathrm{kg}$ body weight) for 30 seconds and blood collection is performed at $-5,0,2,5$, and 10 min from injection..$^{2-5}$ Thus, conditions that cause persistently high levels of calcium, 
such as hyperparathyroidism and others, may lead to higher levels of calcitonin.

Renal insufficiency: The calcitonin clearance rate is lowered in patients with chronic renal insufficiency. This effect may lead to increased levels of calcitonin in the blood. ${ }^{17,18}$

Thyroid carcinomas: Follicular and papillary thyroid carcinomas have been reported to be associated with $\mathrm{C}$-cell hyperplasia and high levels of calcitonin., ${ }^{2,9,10,25}$ It has been proposed that these tumors may release substances that possess a paracrine stimulatory action on the $\mathrm{C}$-cells and will thus eventually raise serum calcitonin levels.

Neuroendocrine tumors: Several types of neuroendocrine tumors can ectopically secrete calcitonin. Such tumors, including paragangliomas, might be associated with increased levels of calcitonin, even in cases where there is a negative immunohistochemistry reaction for calcitonin. ${ }^{26}$ Hypercalcitoninemia has also been reported in patients with pheochromocytoma, enteropancreatic endocrine tumors, VIPomas, insulinomas, gastric carcinoids and small cells pulmonary tumors. ${ }^{15,16,22}$

Chronic autoimmune thyroiditis: As yet, no general consensus has been achieved regarding the levels of calcitonin in Hashimoto thyroiditis. Barbot et al. reported high calcitonin levels in $3 / 24$ patients $(12.5 \%)$ with Hashimoto thyroiditis. ${ }^{27}$ Others stated that up to $20 \%$ of patients with chronic lymphocytic thyroiditis present C-cell hyperplasia ${ }^{28}$ that may lead to increased calcitonin levels. We analyzed calcitonin responses during a calcium/ pentagastrin infusion test in 27 patients with chronic autoimmune thyroiditis (CAT) during either the goitrous (early) or agoitrous/atrophic (late) stages of this disease and in 30 healthy adult controls. ${ }^{11}$ Sixteen cases were diagnosed at the advanced, atrophic thyroid stage of CAT and eleven cases at the early, goitrous stage. We found significantly lowered basal and stimulated calcitonin values in patients at both stages of CAT. These findings were confirmed by other studies. ${ }^{12}$ The limited secretory reserve of calcitonin noted in these CAT cases may be a consequence of a progressive C-cell destruction following nonspecific follicular and parafollicular cell damage caused by progressive lymphocytic infiltration and fibrosis of the thyroid gland. ${ }^{29}$ In another study, a significant decrease in C-cell number was observed in cases with CAT compared to normal thyroids. These data indicate that the inflammatory process caused destruction of both follicular and C cells, which were ultimately replaced by fibrosis. ${ }^{30}$

Other secretagogues: Many drugs have been reported to raise calcitonin serum levels, such as glucocorticoids, glucagon, CGRP, enteroglucagon, pancreozimine, and beta blockers. $^{2}$
Physiologic conditions: Sex, age and physical activity may affect the synthesis and/or secretion of calcitonin., ${ }^{2,24,25}$ More specifically, physical activity can induce small elevations in the calcitonin level; women present lower basal calcitonin levels $(<5 \mathrm{pg} / \mathrm{ml})$ compared to men $(<8.5$ $\mathrm{pg} / \mathrm{ml}$ ); and the elderly present lower levels than younger individuals.

\section{False positive results and erroneous indication of total thyroidectomy}

Considering the above information, it is not surprising that false-positive calcitonin results have led to erroneous recommendations of total thyroidectomy. ${ }^{7,8,25,31,32}$

Høie and colleagues ${ }^{8}$ reported a multiple endocrine neoplasia type 2 (MEN2A) family in which two relatives were recommended for preventive total thyroidectomy based on their high levels of calcitonin; one of the relatives was a 6-year-old child. Later, both cases were confirmed as having no germline RET mutation. Marsh and colleagues ${ }^{7}$ similarly reported two patients belonging to a MEN2A family who underwent total thyroidectomy based solely on their calcitonin levels. Soon after, both individuals were confirmed as being negative for the RET mutation. Therefore, the recommendation and surgical option of total thyroidectomy were inappropriate for both families.

Similarly, Papapetrou and colleagues ${ }^{21}$ reported a patient who underwent total thyroidectomy due to the detection of high levels of calcitonin that were, in fact, caused by anticalcitonin antibodies. In 2007, Galitz and colleagues ${ }^{25}$ showed that four patients with thyroid nodules and high serum levels of calcitonin were recommended for total thyroidectomy. However, the pathologic findings revealed either lymphocytic thyroiditis or papillary thyroid carcinoma in these cases.

We followed up two young girls belonging to a MEN2 family who were recommended for preventive total thyroidectomy in another hospital based on slightly increased basal calcitonin levels. Soon after, RET mutation analysis performed in our laboratory revealed that neither atrisk girl harbored any RET mutation in the six examined hotspot exons. The germline RET Cys620Arg mutation found in other at risk members of this family were not present in these two young girls (manuscript in preparation).

Therefore, in order to avoid misdiagnosis and unnecessary thyroid surgeries, it is imperative to conduct a thorough investigation in cases with elevated basal levels of calcitonin to exclude possible diagnoses other than MTC (Table 1).

\section{An approach for individuals at-risk for MTC}

The National Institute of Health (NIH) guidelines for 
MEN patients recommends that all cases of MTC, either sporadic or inherited, should be analyzed for mutations in the RET proto-oncogene. ${ }^{4}$ As has been stated, RET molecular diagnosis is considered the gold-standard for the recognition of patients at-risk for MTC in MEN2 families. ${ }^{4}$ For the great majority of asymptomatic carriers of RET protooncogene mutations, a prophylactic total thyroidectomy is recommended before 5 years of age. ${ }^{4}$

\section{Calcitonin measurements in thyroid nodules}

The routine measurement of calcitonin to screen for MTC in patients with nodular thyroid disease is still controversial. Several researchers recommend it, 9,32-35 including the European consensus group. ${ }^{36}$ However, the American Thyroid Association ${ }^{37}$ has raised concerns about some possible limitations to this procedure. Although only $10 \%$ to $40 \%$ of patients with thyroid nodules and high levels calcitonin may harbor an MTC, routine calcitonin measurement in these cases (mostly in those with solid nodules) has been demonstrated to be beneficial. ${ }^{9}$

Frequently, patients with MTC (mostly those with the sporadic form) are diagnosed at a later stage of the disease. Many of these cases will be recognized only after the detection of a single palpable thyroid nodule (larger than $1 \mathrm{~cm}$ in diameter), hypercalcitoninemia and cytologic and pathologic findings compatible with MTC. Whenever a patient presents a palpable nodule, the MTC tumor will have evolved for nearly 4 years and have a $50 \%$ to $70 \%$ risk for cervical lymph node metastases..$^{2-4}$

Constante et al. ${ }^{33}$ measured serum calcitonin values in 5,815 patients with thyroid nodules. Of these patients, 15 were diagnosed with MTC and 7 with C-cell hyperplasia. They reported that stimulated calcitonin values of above 100 $\mathrm{pg} / \mathrm{ml}$, after pentagastrin infusion, predicted MTC in $40 \%$ of cases. In the experience of the authors, basal calcitonin values higher than $100 \mathrm{pg} / \mathrm{ml}$ are $100 \%$ predictive of MTC; values between 50 and $100 \mathrm{pg} / \mathrm{ml}$ are $25 \%$ predictive of MTC, and values from 20 to $50 \mathrm{pg} / \mathrm{ml}$ are only $8.3 \%$ predictive of MTC (Table 2).

Scheuba et al. ${ }^{38}$ studied basal and stimulated calcitonin values in 260 patients with thyroid nodules and hypercalcitoninemia. They concluded that all patients with basal calcitonin levels above $64 \mathrm{pg} / \mathrm{ml}$ and stimulated calcitonin values above $560 \mathrm{pg} / \mathrm{ml}$ presented MTC. They also reported that MTC was documented in $20 \%$ of patients with basal calcitonin values ranging from $10 \mathrm{pg} / \mathrm{ml}$ to $64 \mathrm{pg} /$ $\mathrm{ml}$ and calcitonin-stimulated levels ranging from $100 \mathrm{pg} / \mathrm{ml}$ to $560 \mathrm{pg} / \mathrm{ml}$.

Borget et al. ${ }^{9}$ estimated that of about 74,000 patients with thyroid nodules in France, 3,600 of them have elevated levels of calcitonin and, among those, approximately 300 have an MTC. In Brazil, we estimate that there are nearly 220,000 cases with thyroid nodules and that $5 \%$ of them might present high levels of calcitonin. Within the estimated 11,000 patients with hypercalcitoninemia, $10 \%$ to $40 \%(1,100$ to 4,400) might harbor MTC.

Cheung et al. ${ }^{39}$ performed a study to determine the cost-effectiveness $(\mathrm{C} / \mathrm{E})$ of routine calcitonin screening in adult patients with thyroid nodules in the United States of America (USA). They concluded that routine serum calcitonin screening in patients undergoing evaluation for thyroid nodules appears to be cost-effective in USA, with $\mathrm{C} / \mathrm{E}$ comparable to the measurement of thyroid stimulating hormone, colonoscopy, and mammography screenings.

\section{Multiple endocrine neoplasias}

Multiple endocrine neoplasias (MENs) were recently pointed to as a representation of the syndromes of the $20^{\text {th }}$ century, as they were first described in the early 1900s and their clinical, biochemical and molecular features were fully defined by $2000 .^{40}$

MEN type 1 (MEN1) encompasses a series of up to 20 endocrine and non-endocrine tumors caused by a mutation in the tumor suppression gene MEN1. ${ }^{2-4}$ The impact of the description of MEN1 mutations in the clinical approach taken with $M E N 1$ patients has been evaluated in several studies. $^{4,41-43}$ Recent data indicate that other genes, such as p27Kip1, may be involved in cases with MEN1-like phenotypes. $^{44,45}$

Multiple endocrine neoplasia type 2 (MEN2) is characterized by the occurrence of MTC, primary hyperparathyroidism (HPT) and pheochromocytoma. It is caused by germline mutations in the RET proto-oncogene..$^{2-4}$

MTC represents approximately $5 \%$ of all thyroid carcinomas, and from $0.5 \%$ to $1 \%$ of all thyroid nodules. ${ }^{2,3,9}$ Up to $70 \%$ of patients with MTC present with the sporadic form of the disease (s-MTC), frequently related to somatic mutations; the other $30 \%$ of cases present with the inherited forms of MTC caused by germline mutations in the RET proto-oncogene ${ }^{4}$. These two forms of MTC are markedly distinct and should be recognized as such to allow for adequate management. ${ }^{2-4}$

\section{Sporadic medullary thyroid carcinoma (s-MTC)}

s-MTC typically occurs at a later age than the inherited forms of MTC. It is characterized by the presence of a single, unilateral thyroid nodule and the absence of other tumors associated with MTC, such as pheochromocytoma and HPT. There are no similar cases in the family of 
the affected individuals. Measurements of calcitonin in these cases remain a powerful tool for diagnosis, ${ }^{3}$ and thus abnormally high levels of calcitonin $(>100 \mathrm{pg} / \mathrm{ml})$ in patients with or without a thyroid nodule may be indicative of MTC. ${ }^{2-4,46}$ These patients do not have a germline mutation in the RET proto-oncogene, but $20 \%-40 \%$ may present with a somatic mutation of the RET proto-oncogene, most commonly at codon 918 (M918T c.2753T $>$ C), in the thyroid tumor tissue. It is reported that up to $5 \%$ of apparent s-MTC cases may harbor an unsuspected germline RET mutation. ${ }^{2-4,46}$

\section{Inherited medullary thyroid carcinoma}

Inherited MTC occurs at earlier ages than s-MTC and always presents at a pre-malignant $\mathrm{C}$-cell hyperplasia stage. It is usually bilateral and caused by activating mutations in the RET gene, which encodes the RET receptor ${ }^{2-}{ }^{-4,10,13,28,47,48}$ MTC occurs as the predominant component of MEN2 syndromes: ${ }^{2,3}$ a) familial MTC (F-MTC), in which MTC is the only MEN2-related tumor occurring in at least 10 members of a same family, b) MEN2A, in which MTC is associated with HPT and pheochromocytoma, c) MEN2B, in which MTC is associated with HPT, pheochromocytoma, skeletal abnormalities, and multiple neuromas of the lips, tongue, and gastrointestinal tract. ${ }^{2}$

The analysis of germline mutations in the RET protooncogene is considered the gold-standard for the study of MEN2 families. ${ }^{4,13,49}$ Presently, measurements of calcitonin in patients with inherited MTC are restricted to studies of tumor progression and post-surgical outcomes. ${ }^{4,50}$ As discussed above, pre-surgical calcitonin values in this condition should be carefully interpreted, considering the several reports of false-positive and false-negative results of calcitonin as a marker for MTC. $4,7,8,21,31,50,51$

\section{C-cell hyperplasia}

C-cell hyperplasia $(\mathrm{CCH})$ is indicated by the presence, in a thyroid cross section, of more than $50 \mathrm{C}$-cells in at least three microscope fields (100X magnification) and at least $40 \mathrm{C}$-cells by $\mathrm{cm}^{2}$. CCH is intrinsically related to MTC associated with MEN2 (primary C-cell hyperplasia), but may also occur in a series of other non-inherited endocrine and non-endocrine disorders (secondary C-cell hyperplasia). ${ }^{2-4,10}$ Surprisingly, up to $20 \%$ of normal individuals may present with this condition. ${ }^{14}$

Thus, CCH is not pathognomonic of MTC associated with MEN2. CCH is usually related to augmented calcitonin synthesis and secretion, and therefore high serum levels of this hormone. In the set of inherited forms of MTC, $\mathrm{CCH}$ constitutes a progressive and pre-malignant stage. In most MEN2 patients, CCH will evolve to micro-focal MTC and eventually to larger tumors. ${ }^{2}$ Frequently, MTCs in MEN2 are surrounded by extensive areas of $\mathrm{CCH} .{ }^{10}$

\section{Consensus on MENs recommendations}

It is important to follow the recommendations of the NIH Consensus on MENs. ${ }^{4}$ Preventive total thyroidectomy should only be recommended to MTC/MEN2 patients' relatives based on the results of RET mutation analysis, not on calcitonin levels alone. The Consensus also recommends the performance of RET proto-oncogene mutation analysis in all patients with s-MTC, since $5 \%$ of them may have unsuspected RET germline mutations. Hence, calcitonin measurement for screening of at-risk relatives in MEN2 families has been definitively replaced by RET protooncogene mutation analysis, due to the false-positive and false-negative calcitonin results and the high accuracy of RET analysis.

\section{Hospital das Clínicas of the University of São Paulo School of Medicine (HC-FMUSP) experience}

We began studying MTC/MEN2 in the pregenomic phase, when calcitonin measurements and immunohistochemistry analysis were the best available diagnostic tools. ${ }^{1,5,10}$ In the post-genomic phase, we have used automated sequencing mutation analysis of the RET proto-oncogene. ${ }^{47,48}$ In the RET study, we have shown the efficiency of screening methods such as SSCP, DGGE and CSGE. ${ }^{28,47,48,52}$ Abelin et al. ${ }^{34}$ conducted the first measurements of calcitonin in a limited set of patients presenting with a single, solid thyroid nodule and advocate calcitonin measurement as a routine procedure. These authors reported MTC in $~ 1 \%$ of examined cases. We have documented calcitonin deficiency in patients with chronic autoimmune thyroiditis, either in the goitrous or atrophic phase. ${ }^{11}$ Furthermore, the Head and Neck Surgery Group of our institution has established a careful routine surgical procedure for all $R E T$-positive carriers. ${ }^{53}$

\section{CONCLUSIONS}

Some conclusions may be stated from this review. We conclude that:

a) all patients with increased levels of serum calcitonin (with or without thyroid nodule) should be submitted to a careful and thorough investigation in order to rule out conditions other than MTC;

b) preventive total thyroidectomy should be 
recommended and performed in all at-risk relatives of MEN2 patients based on RET mutation analysis, not solely on serum calcitonin levels;

c) although only $10 \%$ to $40 \%$ of unselected cases with hypercalcitoninemia and thyroid nodule will have MTC, routine calcitonin measurements are recommended in these patients in order to reach an earlier MTC diagnosis.

\section{ACKNOWLEDGEMENTS}

The authors wish to thank Dr. Berenice B. Mendonça, Head Professor of Endocrinology, for her review of this manuscript. This research was partially supported by Fundação Faculdade de Medicina and CAPES.

\section{REFERENCES}

1. Borges MF, Abelin N, Toledo SPA. Calcitonina: fisiologia e deficiência. Arq Brasil Endocrinol Metab. 1996;40:67-82.

2. Gagel RF, Marx SJ. Multiple endocrine neoplasia. In: Williams Textbook of Endocrinology. Larsen PR, Kronenberg HM, Melmed S, Polonsky KS (eds). 10th ed. Philadelphia: Saunders; 2003. p. 1717-62.

3. Hoff AO, Cote GJ, Gagel RF. Multiple endocrine neoplasias. Annu Rev Physiol. 2000; 62:377-411.

4. Brandi ML, Gagel RF, Angeli A, Bilezikian JP, Beck-Peccoz P, Bordi $\mathrm{C}$, et al. Guidelines for diagnosis and therapy of MEN type 1 and type 2. J Clin Endocrinol Metab. 2001;86:5658-71.

5. Ezabella MC, Hayashida CY, Bisi H, Leite MO, Borelli A, Abelin $\mathrm{NM}$, et al. Early detection of medullary thyroid carcinoma in multiple endocrine neoplasia type II. Rev Hosp Clin Fac Med Sao Paulo. 1990; 45:105-9.

6. Mulligan LM, Kwok JB, Healey CS, Elsdon MJ, Eng C, Gardner E, et al. Germ-line mutations of the RET proto-oncogene in multiple endocrine neoplasia type 2A. Nature. 1993;363:458-60.

7. Marsh DJ, McDowall D, Hyland VJ, Andrew SD, Schnitzler M, Gaskin EL, et al. The identification of false positive responses to the pentagastrin stimulation test in RET mutation negative members of MEN 2A families. Clin Endocrinol (Oxf). 1996;44:213-20.

8. Høie J, Heimdal K, Nesland JM, Børmer O. Prophylactic thyroidectomy in carriers of $R E T$ oncogene mutation carriers. Tidsskr Nor Laegeforen. 2000;120:3249-52.

9. Borget I, De Pouvourville G, Schlumberger M. Editorial: Calcitonin determination in patients with nodular thyroid disease. J Clin Endocrinol Metab. 2007;92:425-7.
10. Hayashida CY, Alves VA, Kanamura CT, Ezabella MC, Abelin NM, Nicolau W, et al. Immunohistochemistry of medullary thyroid carcinoma and C-cell hyperplasia by an affinity-purified anti-human calcitonin antiserum. Cancer 1993;72:1356-63.

11. Borges MF, Abelin NM, Menezes FO, Dahia PL, Toledo SPA. Calcitonin deficiency in early stages of chronic autoimmune thyroiditis. Clin Endocrinol (Oxf). 1998;49:69-75.

12. Poppe K, Verbruggen LA, Velkeniers B, Finné E, Body JJ, Vanhaelst L. Calcitonin reserve in different stages of atrophic autoimmune thyroiditis. Thyroid. 1999;9:1211-4.

13. Gagel RF. Multiple endocrine neoplasia type II and familial medullary thyroid carcinoma. Impact of genetic screening on management. Cancer Treat Res. 1997;89:421-41.

14. Saint-Andre JP, Guyetant S. Non-neoplastic hypercalcitoninemia. Pathological anatomy. Ann Endocrinol. 1996;57:23-6.

15. Machens A, Haedecke J, Hinze R, Thomusch O, Schneyer U, Dralle H. Hypercalcitoninemia in a sporadic asymptomatic neuroendocrine tumor of the pancreatic tail. Dig Surg. 2000;17:522-4.

16. Freston JW. Omeprazole, hypergastrinemia, and gastric carcinoid tumors. Ann Intern Med. 1994;121:232-3.

17. Niccoli P, Brunet P, Roubicek C, Roux F, Baudin E, Lejeune PJ, et al. Abnormal calcitonin basal levels and pentagastrin response in patients with chronic renal failure on maintenance hemodialysis. Europ J Endocrinol. 1995;132:75-81.

18. Lissak B, Baudin E, Cohen R, Barbot N, Meyrier A, Niccoli P, et al. Pentagastrin testing in patients with renal insufficiency: normal responsivity of mature calcitonin. Thyroid. 1998;8:265-8. 
19. Klinkenberg-Knol EC, Festen HP, Jansen JB, Lamers CB, Nelis F, Snel $\mathrm{P}$, et al. Long-term treatment with omeprazole for refractory reflux esophagitis: efficacy and safety. Ann Intern Med. 1994;121:161-7.

20. McLeod MK, Vinik AI. Calcitonin immunoreactivity and hypercalcitoninemia in two patients with sporadic, nonfamilial, gastroneteropancreatic neuroendocrine tumors. Surgery. 1992;111:4848 .

21. Papapetrou PD, Polymeris A, Karga H, Vaiopoulos G. Heterophilic antibodies causing falsely high serum calcitonin values. J Endocrinol Invest. 2006;29:919-23.

22. Aloia JF, Rasulo P, Deftos LJ,Vaswani A, Yeh JK. Exerciseinduced hypercalcemia and calciotropic hormones. J Lab Clin Med. 1985;106:229-32.

23. d'Herbomez M, Caron P, Bauters C, Cao CD, Schlienger JL, Sapin R, et al. Reference range of serum calcitonin levels in humans: influence of calcitonin assays, sex, age, and cigarette smoking. Eur J Endocrinol. 2007; 157:749-55.

24. Viégas TMRF. Comparação dos testes de estímulo da secreção de calcitonina (omeprazol versus cálcio) no diagnóstico e seguimento de pacientes com carcinoma medular de tireóide. Dissertação de Mestrado. Faculdade de Medicina da Universidade de São Paulo, 2001.

25. Galitz MS, Clyde PW, Sorensen MP, Mohamad-Shakir KM. Diagnosis of C-cell hyperplasia in nodular thyroid disease by calcium stimulation test. The Endocrine Society's 89th Annual Meeting. 2007; p. 713, P4180.

26. Pinto FR, Capelli FA, Maeda SA, Pereira EM, Scarpa MB, Brandão LG. Unusual location of a cervical paraganglioma between the thyroid gland and the common carotid artery: case report. Clinics. 2008; 63:845-8.

27. Barbot N, Guyetant S, Beldent V, Akrass A, Cerf I, Perdrisot R, et al. Chronic autoimmune thyroiditis and C-cell hyperplasia. Study of calcitonin secretion in 24 patients. Ann Endocrinol (Paris). 1991;52:10912 .

28. Toledo SPA, Santos MA, Toledo RA, Lourenço Jr DM. Impact of $R E T$ proto-oncogene analysis on the clinical management of multiple endocrine neoplasia type 2. Clinics. 2006; 61:59-70.

29. Karanikas G, Moameni A, Poetzi C, Zettinig G, Kaserer K, Bieglmayer $\mathrm{C}$, et al. Frequency and relevance of elevated calcitonin levels in patients with neoplastic and nonneoplastic thyroid disease and in healthy subjects. J Clin Endocrinol Metab. 2004; 89:515-9.

30. Lima MA, Santos BM, Borges MF. Quantitative analysis of C cells in Hashimoto's thyroiditis. Thyroid. 1998;8:505-9.

31. Hernández G, Simó R, Oriola J, Mesa J. False-positive results of basal and pentagastrin-stimulated calcitonin in non-gene carriers of multiple endocrine neoplasia type 2A. Thyroid. 1997;7:51-4.

32. Karges W, Dralle H, Raue F, Mann K, Reiners C, Grussendorf M, et al. Calcitonin measurement to detect medullary thyroid carcinoma in nodular goiter: German evidence-based consensus recommendation. Exp Clin Endocrinol Diabetes. 2004;112:52-8.

33. Costante G, Meringolo D, Durante C, Bianchi D, Nocera M, Tumino S, et al. Predictive value of serum calcitonin levels for preoperative diagnosis of medullary thyroid carcinoma in a cohort of 5817 consecutive patients with thyroid nodules. J Clin Endocrinol Metab. 2007;92:450-5.
34. Abelin NMA, Gomes S, Ivanoff MT, Ezabella MCL, Hayashida C, Toledo SPA. Abordagem clínica e laboratorial do bócio uninodular sólido: vantagens da determinação da calcitonina sérica por métodos distintos no rastreamento do carcinoma medular de tireóide, forma esporádica. Arq Bras Endocrinol Metab. 1999;43:104-13.

35. Hauache OM, Vieira JGH, Maciel RMB. Diagnóstico laboratorial do carcinoma medular de tiróide: calcitonina basal e testes de estímulo. Arq Bras Endocrinol Metab. 2003;47:529-33.

36. Pacini F, Schlumberger M, Dralle H, Elisei R, Smit JW, Wiersinga $\mathrm{W}$, et al. European consensus for the management of patients with differentiated thyroid carcinoma of the follicular epithelium. Eur J Endocrinol. 2006;154:787-803

37. Cooper DS, Doherty GM, Haugen BR, Kloos RT, Lee SL, Mandel SJ, et al. Management guidelines for patients with thyroid nodules and differentiated thyroid cancer. Thyroid. 2006;16:109-42.

38. Scheuba C, Kaserer K, Moritz A, Drosten R, Vierhapper H, Bieglmayer $\mathrm{C}$, et al. Sporadic hypercalcitoninemia: clinical and therapeutic consequences. Endocrine-Related Cancer. 2009;16:243-53.

39. Cheung K, Roman SA, Wang TS, Walker HD, Sosa JA. Calcitonin measurement in the evaluation of thyroid nodules in the United States: a cost-effectiveness and decision analysis. J Clin Endocrinol Metab. 2008;93:2173-80

40. Thakker RV. Multiple endocrine neoplasia - syndromes of the twentieth century. J Clin Endocrinol Metab. 1998;83:2617-20.

41. Lourenço-Jr DM, Toledo RA, Coutinho FL, Margarido LC, Siqueira SA, dos Santos MA, et al. The impact of clinical and genetic screenings on the management of the multiple endocrine neoplasia type 1. Clinics. 2007;62:465-76.

42. Toledo RA, Lourenco DM, Coutinho FL, Quedas E, Mackowiack I, Machado MC, et al. Novel MEN1 germline mutations in Brazilian families with multiple endocrine neoplasia type 1. Clin Endocrinol (Oxf). 2007;67:377-84.

43. Lourenço DM Jr, Toledo RA, Mackowiak II, Coutinho FL, Cavalcanti MG, Correia-Deur JEM, et al. Multiple endocrine neoplasia type 1 in Brazil: MEN1 founding mutation, clinical features, and bone mineral density profile. Eur J Endocrinol. 2008;159:259-74.

44. Agarwal SK, Mateo CM, Marx SJ. Rare germline mutations in cyclindependent kinase inhibitor genes in multiple endocrine neoplasia type 1 and related states. J Clin Endocrinol Metab. 2009; 94(5):1826-34.

45. Pellegata NS, Quintanilla-Martinez L, Siggelkow H, Samson E, Bink K, Höfler H, ET al. Germ-line mutations in p27Kip1 cause a multiple endocrine neoplasia syndrome in rats and humans. Proc Natl Acad Sci U S A. 2006; 103(42):15558-63.

46. Correia-Deur JEM, Toledo RA, Imazawa AT, Lourenço-Jr DM, Ezabella MCL, Tavares MR, et al. Sporadic medullary thyroid carcinoma: clinical data from a university hospital. Clinics. 2009;64:379-86.

47. Santos MA, Nunes AB, Abelin N, Ezabella MC, Toledo RA, Lourenço Jr DM, et al. Genetic screening of multiple endocrine neoplasia type 2: experience of the USP Endocrine Genetics Unit. Arq Bras Endocrinol Metabol. 2006;50:7-16.

48. Nunes AB, Ezabella MC, Pereira AC, Krieger JE, Toledo SPA. A novel Val648Ile substitution in RET protooncogene observed in a Cys634Arg multiple endocrine neoplasia type $2 \mathrm{~A}$ kindred presenting with an adrenocorticotropin-producing pheochromocytoma. J Clin Endocrinol Metab. 2002;87:5658-61.

49. Decker RA, Peacock ML, Borst MJ, Sweet JD, Thompson NW 
Progress in genetic screening of multiple endocrine neoplasia type 2A: is calcitonin testing obsolete? Surgery. 1995;118:257-63.

50. Giraudet AL, Al Ghulzan A, Aupérin A, Leboulleux S, Chehboun A, Troalen F, et al. Progression of medullary thyroid carcinoma: assessment with calcitonin and carcinoembryonic antigen doubling times. Eur J Endocrinol. 2008;158:239-46.

51. Tommasi M, Brocchi A, Cappellini A, Raspanti S, Mannelli M. False serum calcitonin high levels using a non-competitive two-site IRMA. J Endocrinol Invest. 2001;24:356-60.
52. Santos MA, Quedas EP, Toledo RD, Lourenço Jr DM, Toledo SPA. Screening of RET gene mutations in multiple endocrine neoplasia type-2 using Conformation Sensitive Gel Electrophoresis (CSGE). Arq Bras Endocrinol Metabol. 2007;51:1468-76.

53. Tavares MR, Michaluart P Jr, Montenegro F, Arap S, Sodré M, Takeda F, et al. Skip Metastases in Medullary Thyroid Carcinoma: A SingleCenter Experience. Surg Today. 2008;38:499-504. 